managerial practice, in three royal ordnance factories where rates of productivity in the output of similar products differ significantly, and are making comparative studies of units in the Metals Division of Imperial Chemical Industries, Ltd.

The fourth type, that of the intensive study of human relations within a particular firm, is represented by the Tavistock Institute's project at the Glacier Metal Co.; while the fifth type, namely, project-investigation of methods for communicating ideas and information, is represented by the experimental use of group discussion method in training supervisors, particularly in the human relations aspects of their work, the use of this method to improve inter-group communication in a firm as a means of dealing with a problem of 'quality control', and an evaluation of a 'training within industry' programme in a section of a firm. Besides these projects, the Panel is also interested in a series initiated by the British Institute of Management and the Medical Research Council, and has discussed with the Occupational Medicine Committee of the latter the problem of collecting and interpreting statistical records designed to throw light on the influence of health on productivity, particularly the incidence and relative importance of different types of illness and injury. The Panel is also studying the effects of compulsory national service on the training and attitude to work of the young industrial worker.

The Panel on Technical Information Services, under the chairmanship of Dr. A. King, continues the work of a committee previously set up under the Advisory Council on Scientific Policy. Attention has first been given to the organisation of such services in Government departments, and the Panel recommends that the Intelligence Division at the headquarters of the Department of Scientific and Industrial Research should be regarded as the focal point to which general requests for technical information from any Government source should be directed, and that its staff should be strengthened as required for this purpose. The Panel has initiated a general inquiry into the services provided by the chief scientific and technical libraries of Britain, and is working in close collaboration with the standing committee set up by the Royal Society to implement the recommendations of the Commonwealth Conference on Scientific Information, particularly those relating to technical libraries, mechanical aids for indexing and selection and an index of research activities.

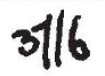

\section{THE CENTENARY OF BEDFORD COLLEGE FOR WOMEN}

$\mathrm{Q}$ UEEN VICTORIA had been only twelve years on the throne whon there was inaugurated in Bedford SquAe, Noidon, a "Ladies' College" at which young wom in might acquire something more than the cist hary, gomewhat vacuous, social background. J's fou l, Mrs. Reid, had dreamed f(r p nears of such a college for women, and it was owing to heraleless effort and zeal that Bedford College opened is doors a full twenty years before Girton College was opened at Hitchin or the idea of Newnham College was conceived.

Mrs. Reid, though far ahead of her time in visualizing her college as a seat of moral culture, would have been overwhelmingly proud, and perhaps not a little surprised, could she see the place it holds in the educational world in its centenary year.

Bedford College owes much to other early pioneers of women's emancipation; such names as Elizabeth Bostock, Eleanor Smith, Jane Martineau, Henrietta Busk and William Shaen, to mention a few, are familiar to all who delve into its past, and many are remembered in more tangible form in connexion with some generous gift or bequest.

The serious obstacle to the accomplishment of Mrs. Reid's dream was that the lack of educational background of the girls of her day made them totally unqualified to benefit by the standard of learning aimed at. By the time the College moved to 8 and 9 , York Place, Baker Street, more and better girls' schools existed, so that when in 1878 the University of London opened its examinations to women, the students from Bedford College were among the first candidates. In 1881 the College recorded its first three graduates in arts, all placed in the first division, and followed the next year by the first B.Sc.; the first M.A. came in 1886. Small beginnings: but what a wealth of initiative, enthusiasm, perseverance and toil had gone into their attainment.

Science, by the very nature of its needs, developed slowly; accommodation and facilities for practical work were at first negligible, the only two laboratories being in the basement kitchens, until in 1889 new laboratories were designed in the rear of York Place.

In 1894 grants from the Government and the London County Council enabled the College to raise its teachers' stipends, lower the students' fees and pro. ceed to increased prosperity less trammelled by financial worries and better directed in its academic life. After 1895 a few departments carried readerships or professorships according to the newly introduced University of London scheme; but it was not until 1929 that the College gained direct representation on the Senate.

With the removal of the College in 1913 to its present home in Regent's Park, a wide expansion occurred; the number of students rose to more than four hundred-Bedford College had become a centre of learning worthy not only in its teaching, but also in the facilities it provided in its dignified buildings with its halls of residence, departmental lecture rooms, well-equipped laboratories, spacious common rooms and fine library set in eight acres of beautiful grounds. Much of this had come about by public appeal and generous benefactions, foremost among the latter being the magnificent gift of $£ 105,000$ for endowment purposes by Sir Hildred Carlile in memory of his mother.

So began another era in the history of the College; but this was unfortunately interrupted by the First World War. After the War, the demand for higher education by women became so great that this, the largest of the women's colleges, was hard put to it to accommodate its students. In 1930 a new building completed the College quadrangle, commemorating in its name Dame Margaret Tuke, principal for twenty-two years, who retired the year before its official opening in 1931 .

Once more there was a period of grace and expan. sion during which several new professorships and readerships were established. The College numbered about six hundred and fifty students and fostered a vigorous intellectual and social life through the thriving students' societies and intercollegiate activities. 
With the outbreak of the Second World War came an upheaval, both bodily and spiritually. Bedford College was evacuated to Cambridge, and though its students and staff appreciated their association with the ancient University, the strain on the staff was considerable in the crowded conditions, the disembodied state of the College and the hectic atmosphere of war. The wisdom of this evacuation was justified when the main building (occupied at the time by the B.B.C.), one science block and the dining hall were destroyed by enemy action in the great fire raid of May $10,1941$.

In 1944 the College returned to London. Readjustments had to be made, as about a third of the buildings had been demolished and many more women were clamouring for a university education. To ease the accommodation of its now 830 students, three of the stately houses in Regent's Park have been acquired.

To-day, the signs of devastation are receding and progress in rebuilding is at last apparent; the dining hall and new mathematics department over it have been in use since October 1948, and though the north science block will be rebuilt later, the main building, it is hoped, will open its doors in 1951.

In the hundred years of its life, 15,000 students have entered the College, two-fifths of these in the last twenty-five years. The majority, particularly of the arts graduates, have entered the teaching profession, and not only are there many principals of training colleges and headmistresses in Great Britain, but also in other parts of the world, including Australia, New Zealand, India, Ceylon, South Africa, West Africa, Nigeria, Tanganyika, Jamaica, Malaya, China and Japan.

It was in its Victorian era that Bedford began to provide leaders in education in the two vice-principals and later a principal of Newnham College, a vice-principal of Somerville College and the founder and first headmistress of Roedean School. From this period, too, came Miss Phillipa Fawcett, who, having been placed above the Senior Wrangler, afterwards served in the Transvaal Education Department and returned later to serve for thirty years as assistant to the Education Officer of the London Councy Council. The first woman barrister was a student of the College in 1857, and in 1880 another graduate became an alderman of the London County Council. Ineidentally, the first woman to be made a professor of the University of London was a member of the College staff, and it is to be recorded with pride that the first woman vice-chancellor of a university within the Commonwealth, the present vice-chancellor of the University of London, is one of Bedford's professors. The science graduates are largely engaged in teaching or research. One of the professors of the University of London is a Bedford graduate, and another is professor of chemistry in a Government college in South Africa. Many are university readers, lecturers and demonstrators, and one of the first two women to be elected as Fellows of the Royal Society was a Bedford graduate. Interesting, too, is the fact that at the present time more than one-third of the women members of one of the learned societies of Great Britain graduated from the College.

Miany past students have turned to librarianship and have become chief librarians of university colleges and also of public and other libraries. The College has sent out many pioneers connected with health and social services, providing one of the first women inspectors under the National Health Act (1913) and the first woman factory inspector in
Sweden. To-day large numbers are engaged in social welfare. Bedford has also provided a pioneer in women's employment who, during a distinguished Civil Service career, became director of women's employment, H.M. Treasury. Miany past students have played their part in other spheres, in journalism, on the stage and as authors, including at least one well-known novelist.

It is to women's education that the College has, perhaps, made its greatest contribution, not only through the representatives in the teaching profession already mentioned, but in the direction of educational films and educational programmes of the B.B.C.

Many have given much to Bedford College and she is deeply sensible of the debt. With the blessing of her patron, H.M. Queen Mary, on her centenary, she stands to-day a proud College of the University of London-the oldest women's university college in the world.

\section{OBITUARIES T/F \\ Dr. Menve Hocken}

Dr. Menvinif focked told me, at his hospitable dinner-table in 146 , that he was born at Cardiff on January 10, 1888, when his parents were cruising off the Wgleh coast-not in Cornwall, as has been gtaped elewhere. He lived with his father, a Thames pilc. Ar Gravesend from the age of four to sixteen, duing which years he discovered mole crickets in Kent and evinced an innate bent for biology, fostered by Moseley's 1892 Challenger voyage, received as a school prize in 1903. His first medical appointment was at the East Suffolk and Ipswich Hospital. In 1914 he joined the R.A.M.C. as senior medical officer at the Martlesham Experimental Station near Ipswich, and later served at Filby on the Norfolk Broads. In 1920, after a short time in Ipswich (like Thomas Muffet in 1585), he moved to the little Suffolk town of Halesworth, where he later bought Adams's commodious brewery house, with its excellent Charles I staircase of appliqué work. Practice so thrived that in 1938 he took two partners; and always another and very true one was his wife, Miss Winifred Triniman, a Cornish farmer's daughter.

For many years, leisure for purely biological study was lacking: Hocken had his way to make in the world. But the urge was innate, if not inherent. $\mathrm{He}$ had studied the British Tortricid moths to some extent before the First World War, and in 1935 his interest in them revived. In $1941 \mathrm{I}$ pointed out the need for investigating the British Tipulidæ (craneflies) ; he promptly joined the Entomological Society of London, secured its publications upon the subject and set himself, with characteristic ardour though already feeling bronchial trouble, to work out the local species. After four years assiduous study in every spare moment, and assistance from other members of the Suffolk Naturalists' Society, which he and Mrs. Hocken had joined in 1936, he published in its annual Transactions (pp. 184-98; 1945) a detailed résumé of the county's 151 known species, out of the 284 that occur in Britain; this was no mean achievement in so short a period. For the rest, he was possessed of a sound general knowledge of both flora and fauna.

In October 1946 Hocken was compelled by growing ill-health to retire from practice, and he went to his ever beloved "West Countrie"; and he died there, at St. Austell, on April 16. Claude Morley 